\title{
Sampling Alternatives for Eucalyptus Trees in Integrated Crop-Livestock-Forest System
}

\author{
Helio Tonini ${ }^{1}$ (D), Charlote Wink ${ }^{2}$ (D), Andrey Gregory da Mota Ferreira e Silva ${ }^{2}$ \\ ${ }^{1}$ Embrapa Pecuária Sul, Bagé/RS, Brasil \\ ${ }^{2}$ Universidade Federal de Mato Grosso - UFMT, Sinop/MT, Brasil
}

\begin{abstract}
The aim of this paper was to compare methods and sampling procedures applied to eucalyptus grown under different spatial arrangements in an integrated crop-livestock-forest system (ICLF). The study was carried out in Sinop county, Mato Grosso state, Brazil. Arrangements combining fixed and variable area methods to simple random and systematic sampling were tested. Precision, accuracy, efficiency, and diameter-distribution measurements were used for selection of the best sampling arrangement. The sampling intensity, sample unit optimal size and the relative efficiency have been changed depending on the spatial arrangement for $10 \%$ sampling error and $95 \%$ probability level. The fixed area method based on systematic sampling, as well as smaller sample units with eight to nine plants $\left(48 \mathrm{~m}^{2}\right.$ to $\left.54 \mathrm{~m}^{2}\right)$ were the most accurate; however, larger plots $\left(192 \mathrm{~m}^{2}\right.$ to $\left.216 \mathrm{~m}^{2}\right)$ were more efficient. All sample units size provided good estimates on the number of trees by diameter classes.
\end{abstract}

Keywords: forest inventory, Eucalyptus grandis $\times$ Eucalyptus urophylla, agroforestry systems. 


\section{INTRODUCTION}

The integrated crop-livestock-forest system (ICLF) applies to the sustainable meat, milk, grain, and forest products production in the same area through intercropping, succession or rotation plantations (Kichel et al., 2014).

The integration between trees, agricultural crops and livestock can lead to complementary benefits. The agricultural activities cover the negative cash flow resulting from the requested forest-investment maturity time. Moreover, the trees provide environmental improvements such as carbon sequestration and dust suspension control, besides climatic condition enhancement. Some of these improvements concern the protection against frost, wind, hail and storms, as well as soil physical, chemical and biological-attribute improvements. These soil enhancements regard increased nutrient cycling, erosion control, pasture-nutrition value increase and water conservation (Paiva \& Vital, 2003; Santos et al., 2010; Porfírio-da-Silva et al., 2010; Ferreira et al., 2014; Balbino et al., 2012). The ICLF adoption in Brazil has grown due to its advantages, and this is the reason why it is expected to be implemented in more than 20 million hectares within the next 20 years (EMBRAPA, 2017). It is worth providing producers with new information in order to assist them at the time of choosing the forest species and collecting performance and productivity data.

The information on trees and forests is gathered by an inventory system used to measure the extent, quantity and condition of the forest resources (Kangas \& Maltamo, 2009). The first forest inventories were carried out in Central Europe in the 14th and 15th centuries, but they were definitely incorporated to forest planning in the early 19th century due to the development of the sampling theory (Asrat \& Tesfaye, 2013). Thenceforth, the sampling theory has been addressed and discussed in several scientific articles published in the specialized literature (Spurr, 1952; Husch, 1971; Loetsch et al., 1973; Vries, 1986; Shiver \& Borders, 1996; Mandallaz, 2008; Kangas \& Maltamo, 2009). Studies such as those performed by Mello et al. (2009), Druszcz et al. (2010), Gomes et al. (2011), Nakajima et al. (2011), Péllico-Netto et al. (2014), and Miranda et al. (2015) sought to assess the accuracy and efficiency of different methods and sampling processes applied to forest plantations. It is worth highlighting that these methods and processes vary depending on forest type, tree species and planting conditions, such as the topographic relief and plant mortality.

Trees are arranged in planting rows and cover a small fraction of the total area in ICLF; thus, this system deals with low tree-density per hectare. This feature does not allow carrying out a complete enumeration just as it happens in forest stands and native forests. However, a good sampling structure can generate accurate information at lower field cost and smaller effort.

Few studies have focused on the inventory of trees in ICFL systems. Authors such as Fick (2011) and Dias (2014) were pioneers in studying tree sampling in these production systems.

Fick (2011) recommended applying the systematic sampling to $10 \%$ of the trees in a silvopastoral system by considering each tree as a sampling unit. Dias (2014) used the modified method of maximum curvature of the coefficient of variation and recommended adopting sample units with seven to eight eucalyptus trees planted in double and triple row arrangements.

The results found by the aforementioned authors contrast the methodology used in studies assessing the performance, biomass production, or tree growth modeling in ICLF (Nicodemo et al., 2009; Azevedo et al., 2009; Salles et al., 2012). Such fact indicates that little attention has been given to the statistical basis at the time of defining the plot size, as well as to define sample size and the way of selecting the trees.

On the other hand, Balandier \& Dupraz (1999) and Nicodemo et al. (2009) opted to use the complete enumeration. Teklehaimanot et al. (2002), Andrade et al. (2008), Oliveira et al. (2009) and Salles et al. (2012) used sample units based on the number of plants selected in the central area of the planting; the number of plants ranged from 20 to 42 and the area, from 180 to $1200 \mathrm{~m}^{2}$. Azevedo et al. (2009) and Oliveira et al. (2008) chose the tree-samples randomization system with 5 to 180 trees.

There were great methodological variations in the studies assessing the forest species' performance in ICLF, thus, it is worth developing data-collection protocols to compare different studies. Therefore, the aim of the current study was to compare methods and sampling procedures using sample units of different sizes in an integrated crop-livestock-forest system with different spatial arrangements. 


\section{MATERIAL AND METHODS}

The study was carried out in the experimental site of Embrapa Agrossilvipastoril (Empresa Brasileira de Pesquisa Agropecuária/Brazilian Agricultural Research Corporation), Sinop county, Mato Grosso state (MT), Brazil, at geographic coordinates $11^{\circ} 51^{\prime} 43^{\prime \prime} \mathrm{S}$ and $55^{\circ} 35^{\prime} 27^{\prime \prime} \mathrm{W}$, altitude $384 \mathrm{~m}$. The mean annual temperature is $25^{\circ} \mathrm{C}$ and the mean annual rainfall is $2550 \mathrm{~mm}$, with dry season from June to September. The prevalent soil type in the site is the Red-Yellow Latosol, at flat relief (Dias, 2014).

The experimental area was established in February 2011 aiming at studying the effect of intercropping trees with piatã grass (Brachiaria brizantha cv. Piatã), silage corn and Girolanda dairy cattle. The experimental area covers 40 ha in total, which are subdivided in four blocks of 10 ha each. The experiment followed a randomized complete block design, with four replications and three treatments. The total absence of trees in the pasture (T0), the presence of peripheral trees in the pasture (T1) and the fully forested pasture area (T2) were taken into account. The experimental plots covered 3.33 ha and the hybrid clone of Eucalyptus grandis $\times$ Eucalyptus urophylla, commercially known as H13, was the forest component of choice. The double-row tree arrangement at $52 \mathrm{~m} \times 3 \mathrm{~m} \times 2 \mathrm{~m}\left(182\right.$ trees ha $\left.\mathrm{h}^{-1}\right)$ spacing was used in $\mathrm{T} 1$ and the triple-row arrangement at $15 \mathrm{~m} \times 3 \mathrm{~m} \times 2 \mathrm{~m}$ spacing $\left(714\right.$ trees $\left.\mathrm{ha}^{-1}\right)$ was adopted in $\mathrm{T} 2$.

The census data collected by Dias (2014) were used to set the population parameters. According to these data, all tree diameters at breast height (DBH) and total heights were measured with electronic hypsometer. Cartesian coordinates, failures and mortality were also taken into account. The total volume with bark $\left(\mathrm{v}_{\mathrm{wb}}\right)$ in each tree rows was calculated by the Schumacher and Hall model (Equation 1), adjusted by Dias (2014), to thirty samples trees using the Smalian method:

$\ln v=-9.66389+1.92184 \ln d+0.8274 \ln h$

where $v$ is total stem volume with bark; $d$ is diameter at breast height; $h$ is total height.

A calculation routine based on the census data was developed in an electronic spreadsheet in order to carry out the sampling simulations.
The sampling system (SS) was based on the combination of methods (variable and fixed area sampling) and procedures (systematic and simple random sampling). The sample units in the fixed area method were rectangular, in plots with 8 (SS 2, area of $48 \mathrm{~m}^{2}$ ), 16 (SS 3, area of $96 \mathrm{~m}^{2}$ ), and 32 (SS 4, area of $192 \mathrm{~m}^{2}$ ) trees in the double-rows arrangement, and of 9 (SS 6, area of $54 \mathrm{~m}^{2}$ ), 18 (SS 7, area of $108 \mathrm{~m}^{2}$ ), and 36 (SS 8, area of $216 \mathrm{~m}^{2}$ ) trees in the triple-rows arrangement. The minimum sampling-unit size followed the recommendation by Dias (2014); the maximum size was defined according to the relation between sampling intensity, number of potential units and experimental area.

The Prodan method, or the six trees variable method, was used as the variable area method (SS 1 and 5). It consists of allocating points in the forest according to any sampling design. Six trees located around this set point are measured in order to set the circular shape of the sample unit. The unit's radius is given by the distance from the sampling point to the last tree (Péllico-Netto \& Brena, 1997).

The sample intensity was defined by preliminary forest inventory conducted in each plot size. It sets the initial sample size at $10 \%$ of the number of potential sample units. According to Péllico-Netto \& Brena (1997), the sample intensity (Equation 2) was found by considering the population variation function, the required precision (10\%) at $95 \%$ probability level.

$n=\frac{N t^{2} s^{2} x}{N E^{2}+t^{2} s^{2} x}$

where: $N$ is number of potential sample units; $t$ is student's $\mathrm{t}$ statistics; $s^{2} x$ is sample variance; $E$ is allowed sampling error.

The definite inventory for each sampling system was simulated based on the sampling intensity definition. The first sampling unit in the systematic process was randomized and the other units were selected according to the $k$ interval (Péllico-Netto \& Brena, 1997). Therefore, the sample intensity changed depending on the sample unit size, rather than on the sampling process, to allow comparisons.

The parameters for each sample were estimated according to Péllico-Netto \& Brena (1997) and Soares et al. (2006), after the selection of the samples. Two simulations were performed in each sampling procedure for each spatial arrangement and 
experimental block, thus totaling 8 replications per SS and 128 simulations. The $10 \%$ sampling error at $95 \%$ probability level was adopted.

The accuracy of the estimated volume was evaluated based on confidence interval, mean standard error and absolute error. The absolute error or the mean diameter and height deviation estimator was used as additional criterion.

The mean standard error (Equation 3) was calculated by dividing the sample's standard deviation by the square root of the sample size:

$\underset{x}{S_{-}}= \pm s / \sqrt{n}$

where $s$ is mean standard error; $n$ is number of sample units.

Accuracy was measured by the absolute inventory error (Equation 4) or by the estimator's deviation (in percentage).

$E A=\frac{x_{r}^{-}-x_{e}^{-}}{x_{e}^{-}} .100$

where $\bar{x}_{r}$ is parametric mean; $\bar{x}_{e}$ is estimated mean.

The weighted value of the statistical scores was used as the best way to select the sampling system (Schneider et al., 2009). The (a) mean standard deviation $\left(S_{x}\right)$; (b) absolute error for the total volume with bark $\left(A E V_{w / b}\right) ;(\mathrm{c})$ absolute error for the estimated mean in $\mathrm{DBH}\left(A E_{d h b}\right)$ and total height $\left(E A_{h}\right)$; and (d) the amplitude of the confidence interval for the total estimated volume with bark $\left(C I T_{t v w b}\right)$ values were ranked from the lowest to the highest value, i.e., from value 1 up to the highest recorded value. The sampling system presenting the lowest sum of the assessed statistical scores was considered the best one.

After the volume estimation in the trees rows $\left(V_{\text {rows }}\right)$, the total volume produced in one hectare $V$ (ha) in the ICLF was obtained (Equations 5 and 6).

$V_{(h a)}=V_{\text {rows }} \cdot A \cdot C$

were $V_{\text {rows }}$ is the estimated volume in the row of trees $\left(\mathrm{m}^{3}\right) ; A$ is ICFL total área (ha); $C$ is the area occupied by trees in the ICFL

$C \%=\frac{(E l \cdot(L-1)+2)}{E r+(L-1) \cdot E_{l}} \cdot 100$

where $E_{r}$ is tree rows distance; $E_{l}$ is trees line spacing; $L$ is number of tree lines.
A new inventory was carried out based on the precision analysis results; the analysis depended on using the installation of sample units of different sizes distributed in a systematic way. The $20 \%$ sample intensity was used in the present experiment, and the $10 \%$ sample error at $95 \%$ probability level was also taken into account.

The T1 held 17.7 and 4 sample units containing $8\left(48 \mathrm{~m}^{2}\right), 16\left(96 \mathrm{~m}^{2}\right)$ and $32\left(192 \mathrm{~m}^{2}\right)$ trees; and T2 held 18.9 and 4 sample units containing $9\left(54 \mathrm{~m}^{2}\right)$, $18\left(108 \mathrm{~m}^{2}\right)$, and $36\left(216 \mathrm{~m}^{2}\right)$ trees.

The field team was composed of three people trained to measure and record the collected data. The trees' $\mathrm{DHB}(\mathrm{cm})$ and total height $(\mathrm{m})$ were measured in each sample unit by using a diametric tape and an electronic hypsometer. A chronometer helped recording the time (in minutes) needed to perform the inventory, assessing the time spent to allocate the sample units and measuring the dendrometric variables, and the displacement among plots.

Subsequently, the relative efficiency $(E)$ of each sample unit size was set according to Freese (1962) apud Péllico-Netto \& Brena (1997) by considering the coefficient of variation $(C V)$ of the total volume with bark (Equation 7). The sampling presenting the highest value was accepted as being more efficient.

$E=\frac{1}{T C V^{2}}$

where: $E$ is efficiency; $T$ is total time ( $\mathrm{min}) ; C V$ is coefficient of variation.

To search effects of sample unit size on its ability to represent the tree diametric distribution in classes, we fitted Weibull probability function (Equation 8) by the percentiles method and compared using Kolmogorov-Smirnov test at 5\% significance level.

$f(x)=\frac{\gamma}{\beta}\left(\frac{x-\alpha}{\beta}\right)^{\gamma-1} \exp -\left(\frac{x-\alpha}{\beta}\right)^{\gamma}$ for $x>\alpha, \gamma>0$

where: $x$ is diameter center class; $\alpha$ is location parameter; $\beta$ is scale parameter; $\gamma$ is form parameter.

\section{RESULTS AND DISCUSSION}

The sample intensity ranged from 20 to $27 \%$ in $\mathrm{T} 1$ and from 18 to $21 \%$ in $\mathrm{T} 2$ at $10 \%$ sample error and $95 \%$ probability level (Table 1 ). The sampling 
Table 1. Estimates and precision of the sampling procedures applied to eucalyptus trees cultivated in double and triple rows in an integrated crop-livestock-forest system.

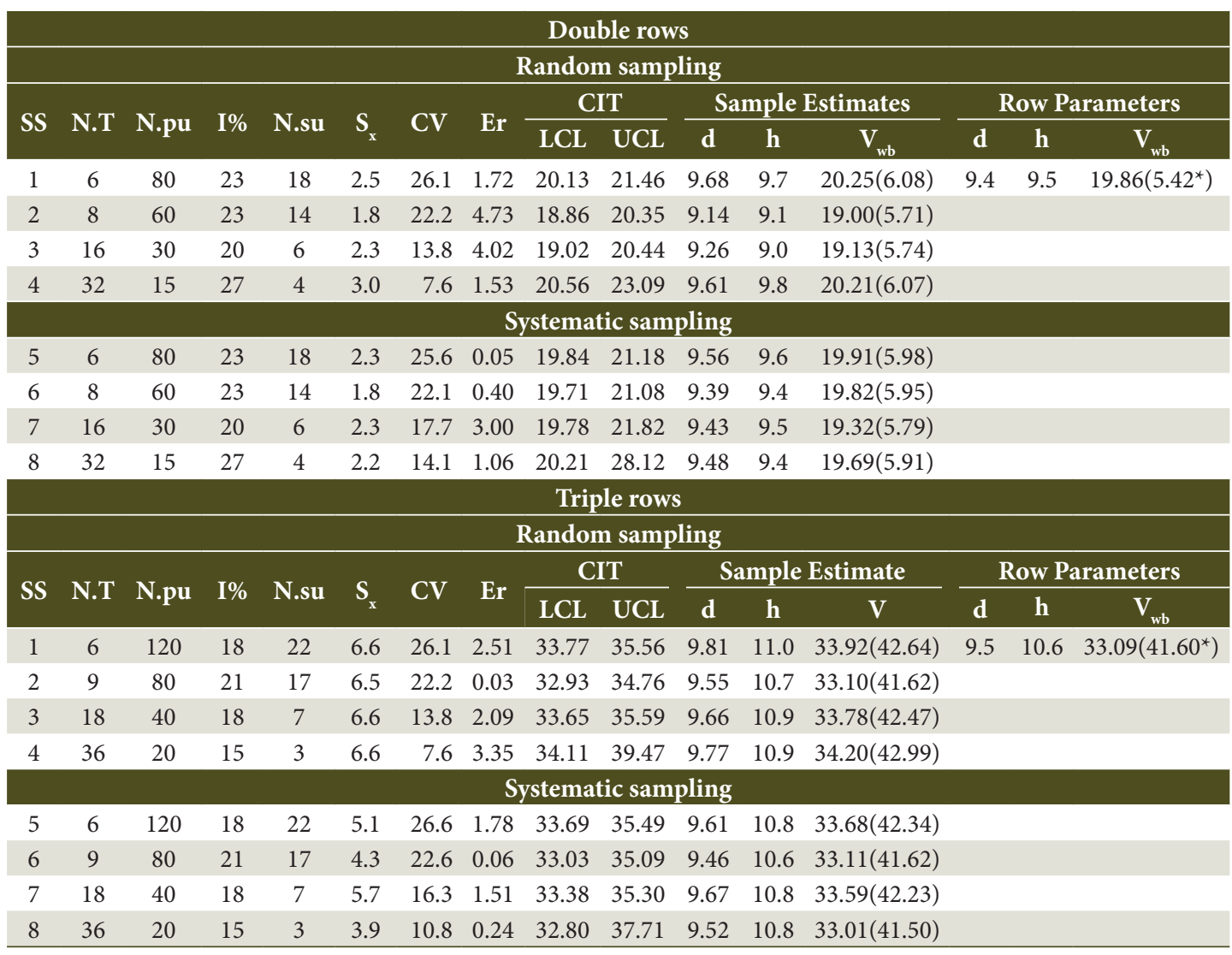

SS is sampling system; N.T is number of trees; N.pu is number of potential units; I\% is sample intensity; N.su is number of sampled units; $\mathrm{S}_{\mathrm{x}}$ is standard error of the mean; $\mathrm{CV}$ is coefficient of variation; $\mathrm{Er}$ is absolute error $\left(\mathrm{m}^{3}\right)$; CIT is confidence interval of the total $\left(\mathrm{m}^{3} \mathrm{ha}^{-1}\right)$; LCL is lower confidence limit; UCL is upper confidence limit; $\mathrm{d}$ is diameter at breast height $(\mathrm{cm})$; $\mathrm{h}$ is total height $(\mathrm{m})$; $\mathrm{V}_{\mathrm{wb}}$ is total volume with bark in trees rows $\left(\mathrm{m}^{3}\right)$; ${ }^{*}$ volume of wood produced in one hectare in ICLF system.

systems 1,4 , and 8 in T1, and 1, 3, 4, 5, and 7 in T2 did not present good estimated volume, since the confidence interval of the total estimated volume with bark did not reach the parametric value. According to Shiver \& Borders (1996), such result derives from the sampling error magnitude, i.e., high magnitudes make the estimates unrepresentative of the population.

The sample system 5 (Prodan Method systematically applied) in $\mathrm{T} 1$ presented the best volume estimates, the lowest absolute error and the shortest confidence interval amplitude. However, the sample system 6 presented the best overall estimates (Table 2). The sample system 6 (systematic sampling containing sample units with 9 plants and $54 \mathrm{~m}^{2}$ ) in T2 presented the best volume estimates.

It was observed that the spatial arrangement had influence on the definition of the sample unit's optimal size, thus emphasizing the importance of adapting the sampling method to the forest conditions (i.e., the planting arrangement) because it allowed to increase precision at the same sample effort (Kangas \& Maltamo, 2009).

There was precision superiority in the fixed-area method based on systematic sampling and smaller sample units holding few measurable trees. This result corroborated Fick (2011) and Dias (2014), who noticed that small sample units can be used in forest inventories in ICLF systems.

Plot size was different from the one commonly recommended by the forest literature on monoculture tree plantations. Circular or rectangular sample units with area ranging from $300 \mathrm{~m}^{2}$ to $600 \mathrm{~m}^{2}$ are used in forest stands in Brazil (Soares et al., 2006), and Spurr (1952) recommended sample units of 
Table 2. Precision and accuracy measurement scores of the sampling systems applied to eucalyptus trees cultivated in double and triple rows in an integrated crop-livestock-forest system.

\begin{tabular}{|c|c|c|c|c|c|c|}
\hline \multicolumn{7}{|c|}{ T1 (double line rows) } \\
\hline SS & $\mathbf{S}_{\mathrm{x}}$ & $\mathrm{EA}_{\mathrm{Vcc}}$ & $\mathrm{CIT}_{\mathrm{Vcc}}$ & $\mathbf{E A}_{\text {dap }}$ & $\mathbf{E A}_{h}$ & Total (m) \\
\hline 2 & 1 & 5 & 4 & 4 & 3 & 17 \\
\hline 3 & 2 & 4 & 3 & 5 & 4 & 18 \\
\hline 5 & 2 & 1 & 1 & 3 & 2 & 9 \\
\hline 6 & 1 & 2 & 2 & 1 & 2 & 8 \\
\hline 7 & 2 & 3 & 5 & 2 & 1 & 13 \\
\hline \multicolumn{7}{|c|}{ T2 (triple line rows) } \\
\hline 2 & 3 & 1 & 2 & 3 & 2 & 11 \\
\hline 6 & 2 & 2 & 1 & 2 & 1 & 8 \\
\hline 8 & 1 & 3 & 3 & 1 & 3 & 11 \\
\hline
\end{tabular}

SS is sampling system; $\mathrm{S}_{\mathrm{v}}$ is Mean standard error; $\mathrm{EA}_{\mathrm{vcc}}$ is volume whit bark absolute error $\left(\mathrm{m}^{3}\right)$; $\mathrm{CIT}_{\mathrm{vcc}}$ is confidence interval of the total volume whit bark $\left(\mathrm{m}^{3}\right)$; $\mathrm{EA}_{\text {dap }}$ is Diameter at breast height absolute error $(\mathrm{cm})$; $\mathrm{EA}_{\mathrm{h}}$ is total height absolute error $(\mathrm{m})$.

$100 \mathrm{~m}^{2}$ to $1000 \mathrm{~m}^{2}$ (1 to $10 \%$ of a hectare) holding at least 20 to 30 measurable trees.

Fick (2011) also observed a better systematic process performance in the silvopastoral system. The main advantages of using this process is time saving, besides the lower costs demanded to allocate the sample units and the best sample units' distribution in the target population (Péllico-Netto \& Brena, 1997; Soares et al., 2006). Its main disadvantage is the impossibility to derive an estimator for the mean variance, since there is no independence when selecting the sample units (Soares et al., 2006; Kangas \& Maltamo, 2009). However, the variance estimate of the random sampling can be used to estimate the systematic sampling variance, except for populations presenting periodic variations (Shiver \& Borders, 1996) because, in this case, this sampling process should be avoided.

The satisfactory performance of the Prodan's method in the double-row planting arrangement evidenced that the variable-area method may be an option for the ICLF inventory, mainly when one wants to quickly and accurately estimate the volume in forest inventories at once. The time saved due to the adoption of proportional distance selection methods allows applying a larger sample and it provides better forest area coverage (Gomes et al., 2011). However, circular samples (as used in the Prodan's Method) are not the most suitable for ICLF because the most part of its area is not occupied by forest species (Fick, 2011). The advantage of having a smaller perimeter and of minimizing marginal-tree occurrences (Loetsch et al., 1973) is of little importance for the commonly adopted arrangements in ICLF systems, since the problem concerning marginal trees planted in rows, with one or more lines is irrelevant.

Regardless of the planting arrangement, the mean displacement, installation and measurement times decreased depending on the plot size (Table 3). Smaller samples demanded $28.8 \%$ to $30.7 \%$ of the time spent in larger samples in the double and triple-row arrangements. However, the smaller sample units required longer total time, since it was necessary installing and measuring a larger number of small samples to assess the same sample intensity.

The measurement demanded the longest time (Figure 1) and was decisive for forest inventory efficiency. Small sample units were measured faster than the larger ones ( $74 \%$ of the time in T1, and $75 \%$ of it in T2). However, measuring few large plots required shorter total time than measuring many small plots.

Efficiency changed depending on the planting arrangement, and this result confirmed Nakajima et al. (2011), who stated that there is no sampling system applicable to all situations.

The sample-unit size that provides the best accuracy is not necessarily the most efficient one (Miranda et al., 2015). The greatest efficiency was shown by plots holding 32 plants $\left(192 \mathrm{~m}^{2}\right)$ in T1; and by those holding 18 plants $\left(108 \mathrm{~m}^{2}\right)$ in $\mathrm{T} 2$. These results differed from those found by inventory accuracy analysis.

Therefore, the objectives, time and available resources must be considered at the time of selecting the sample-systems. One must notice that small sample 
units lose representativeness when the aim is to monitor forest populations subjected to tree density reduction processes such as thinning for long periods-of-time (Soares et al., 2006).

The Kolmogorov-Smirnov test analysis, applied to different sample-unit sizes in order to verify their capacity to represent the tree diameter distribution (Figure 2), showed no significant difference. Thus, all the herein assessed sample-unit sizes presented frequencies close to those observed in the census. They also well-represented the trees' diameter structure in both planting arrangements.

Table 3. Timing, coefficient of variation and relative efficiency of the forest inventory of Eucalyptus trees cultivated in integrated crop-livestock-forest system in double (T1) and triple (T2) rows.

\begin{tabular}{|c|c|c|c|c|c|c|c|c|c|c|}
\hline \multicolumn{11}{|c|}{ T1 } \\
\hline \multirow{2}{*}{$\begin{array}{l}\text { Area } \\
\left(\mathrm{m}^{2}\right)\end{array}$} & \multicolumn{4}{|c|}{ Unit time (min) } & \multicolumn{4}{|c|}{ Total time (min) } & \multirow{2}{*}{ CV (\%) } & \multirow{2}{*}{ RE } \\
\hline & Displ. & Inst. & Meas. & Total & Displ. & Inst. & Meas. & Total & & \\
\hline 48 & 0.42 & 0.55 & 2.38 & 3.38 & 5.97 & 8.00 & 33.30 & 47.27 & 25.92 & 0.031 \\
\hline 96 & 0.74 & 0.64 & 4.75 & 6.13 & 5.21 & 4.53 & 33.19 & 42.93 & 23.23 & 0.043 \\
\hline 192 & 1.03 & 0.85 & 9.86 & 11.73 & 4.11 & 3.40 & 39.43 & 46.94 & 17.54 & 0.069 \\
\hline \multicolumn{11}{|c|}{ T2 } \\
\hline \multirow{2}{*}{$\begin{array}{l}\text { Area } \\
\left(\mathbf{m}^{2}\right)\end{array}$} & \multicolumn{4}{|c|}{ Unit time (min) } & \multicolumn{4}{|c|}{ Total time (min) } & \multirow{2}{*}{ CV (\%) } & \multirow{2}{*}{ RE } \\
\hline & Desl. & Inst. & Med. & Total & Desl. & Inst. & Med. & Total & & \\
\hline 54 & 0.29 & 0.62 & 2.83 & 3.77 & 5.83 & 11.1 & 51.01 & 67.90 & 24.37 & 0.024 \\
\hline 108 & 0.55 & 0.75 & 5.43 & 6.75 & 5.00 & 6.82 & 48.92 & 60.70 & 13.31 & 0.093 \\
\hline 216 & 1.28 & 0.88 & 10.1 & 12.26 & 5.1 & 3.52 & 40.4 & 49.03 & 9.11 & 0.002 \\
\hline
\end{tabular}

Displ. is displacement; Inst. is installation; Meas. is Measurement; CV is coefficient of variation; RE is relative efficiency.
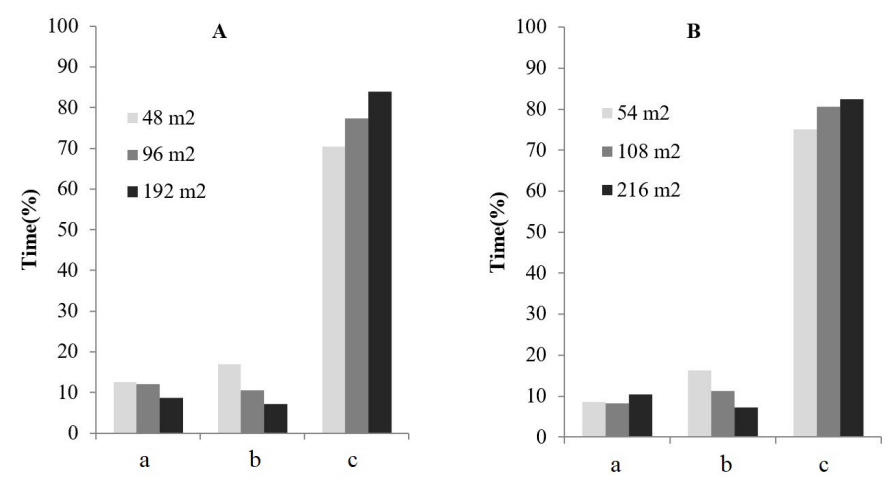

Figure 1. Time consumption (\%) of sample-unity size and of planting arrangement in double (A) and triple (B) rows. (a) is displacement; (b) is installation; (c) is measurement.

A

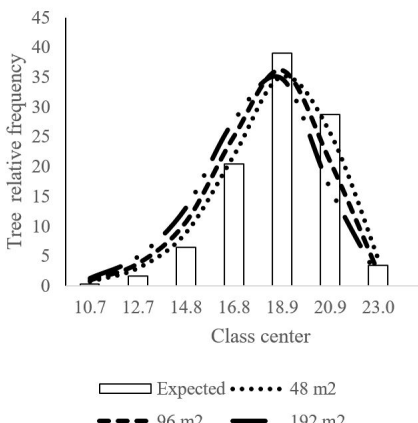

- $-96 \mathrm{~m} 2$ - $192 \mathrm{~m} 2$
B

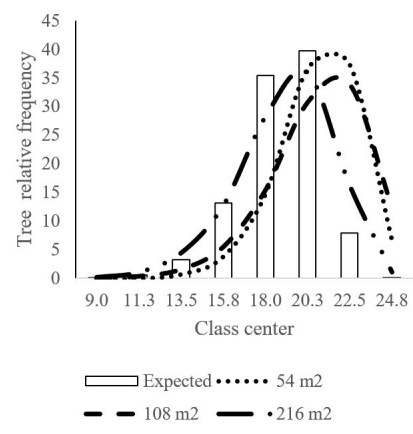

Figure 2. Estimated relative frequency of eucalyptus trees by diameter class in double (A) and triple (B) rows in sampling units of different sizes. 


\section{CONCLUSIONS}

Sampling intensity, optimum sample size and relative efficiency have changed according to the planting spatial arrangement, fact that emphasizes the importance of adjusting the sampling method to the forest planting conditions in integrated crop-livestock-forest systems.

The fixed area method based on a systematic sampling process and on smaller sample units holding 8 to 9 plants $\left(48 \mathrm{~m}^{2}\right.$ to $\left.54 \mathrm{~m}^{2}\right)$ was the most accurate one. However, larger plots $\left(192 \mathrm{~m}^{2}\right.$ to $\left.216 \mathrm{~m}^{2}\right)$ have provided greater forest inventory efficiency. All sample-units sizes provided good estimates of the number of trees by diameter classes.

\section{SUBMISSION STATUS}

Received: 25 aug., 2017

Accepted: 30 june, 2018

\section{CORRESPONDENCE TO}

\section{Helio Tonini}

Embrapa Pecuária Sul, Rodovia BR-153, Km 632,9, Vila Industrial, Zona Rural, CEP 96401-970, Bagé, RS, Brasil e-mail: helio.tonini@embrapa.br

\section{REFERENCES}

Andrade HJ, Brook R, Ibrahim M. Growth, production and carbon sequestration of silvopastoral systems with native timber species in the dry lowlands of Costa Rica. Plant and Soil 2008; 308(1-2): 11-22. http://dx.doi.org/10.1007/ s11104-008-9600-x.

Asrat Z, Tesfaye Y. Training manual on forest inventory and management in the context of SFM and REDD+. Hawassa: Hawasa University; 2013.

Azevedo CMBC, Veiga JB, Yared JAG, Marques LT. Desempenho de espécies florestais e pastagens em sistemas silvipastoris no Estado do Pará. Pesquisa Florestal Brasileira 2009; 60: 57-65.

Balandier P, Dupraz C. Growth of widely spaced trees: a case study from young agroflorestry plantations in France. Agroforestry Systems 1999; 43(1-3): 151-167. http://dx.doi. org/10.1023/A:1026480028915.

Balbino LC, Cordeiro LAM, Oliveira P, Kluthcousk J, Galerani PR, Vilela LP. Agricultura sustentável por meio da integração lavoura-pecuária-floresta. Informações Agronômicas 2012; 138: 1-18.
Dias TC. Forma e tamanhos ótimos de parcelas experimentais de Eucalyptus urograndis em sistema de integração lavoura pecuária floresta [online]. Lavras: Universidade Federal de Lavras; 2014 [cited 2014 June 7]. Available from: http:// repositorio.ufla.br/handle/1/3793

Druszcz JP, Nakagima NY, Pellico-Netto S, Yoshitani M Jr. Comparação entre os métodos de amostragem de Bitterlich e de área fixa com parcela circular em plantação de Pinus Taeda. Floresta 2010; 40(4): 739-754.

Empresa Brasileira de Pesquisa Agropecuária - EMBRAPA. Integração lavoura pecuária floresta [online]. Brasília; 2017 [cited 2017 Feb 15]. Available from: https://www. embrapa.br

Ferreira AD, Serra AP, Melotto AM, Bungenstab DJ, Laura VA. Tree management and wood properties in integrated crop-livestock-forestry systems with Eucalyptus. In: Bungenstab D J, Almeida RG, editors. Integrated crop-livestock-forestry systems: a Brazilian experience for sustainable farming. Brasilia: Embrapa; 2014.

Fick TA. Amostragem para inventário florestal em sistemas silvipastoris. Revista Árvore 2011; 35(5): 1033-1038. http:// dx.doi.org/10.1590/S0100-67622011000600009.

Gomes KBP, Machado VA Fo, Silva VP, Silva AG. Comparação de métodos de amostragem casual simples: Bitterlich e Prodan. Revista Agroambiental 2011; 3(1): 101-104.

Husch B. Planning a forest inventory. Rome: FAO; 1971.

Kangas A, Maltamo M. Forest inventory, methodology and applications. Dordrecht: Springer; 2009.

Kichel AN, Costa JAA, Almeida RG, Paulino VT. Sistemas de integração lavoura-pecuária-floresta (ILPF): experiências no Brasil. Boletim de Indústria Animal 2014; 71(1): 94-105. http://dx.doi.org/10.17523/bia.v71n1p94.

Loetsch F, Zohrer F, Haller KF. Statistics of forest inventory and information from aerial photographs. 2nd ed. Munich: BLV Verlagsgesellchaft; 1973.

Mandallaz D. Sampling techniques for forest inventories. Zurich: Chapman \& Hall; 2008.

Mello JM, Diniz FS, Oliveira AD, Scolforo JRS, AcerbiJunior FW, Thiersch CR. Métodos de amostragem e geoestatística para a estimativa de número de fustes e volume em plantios de Eucalyptus grandis. Floresta 2009; 39(1): 157-166. http://dx.doi.org/10.5380/rf.v39i1.13735.

Miranda DLC, Sander A, Gouveia DM. Tamanho e forma de parcelas de área fixa em plantios de teca no norte de Mato Grosso. Nativa 2015; 3(2): 89-94. http://dx.doi. org/10.14583/2318-7670.v03n02a03.

Nakajima NY, Péllico-Netto S, Druszcz JP, Yoshitani M Jr. Comparação de precisão entre os métodos de amostragem em linha e parcela circular concêntrica em povoamentos de Pinus elliotii. Revista Acadêmica de Ciências Agrárias e Ambientais 2011; 9(2): 131-139. 
Nicodemo MLF, Porfirio da Silva V, Santos PM, Vinholis MMB, Freitas AR, Caputti G. Desenvolvimento inicial de espécies florestais em sistema silvipastoril na região sudeste. Pesquisa Florestal Brasileira 2009; 60: 89-92.

Oliveira CHR, Reis GG, Reis MGF, Xavier A, Stocks JJ. Area foliar e biomassa de plantas intactas e de brotações de plantas jovens de clone de eucalipto em sistemas agrossilvipastoris. Revista Árvore 2008; 32(1): 59-68. http://dx.doi.org/10.1590/S0100-67622008000100008.

Oliveira TK, Macedo RGL, Venturin N, Higashikawa EM. Desempenho silvicultural e produtivo de eucalipto sob diferentes arranjos espaciais em sistema agrossilvipastoril. Pesquisa Florestal Brasileira 2009; 60: 1-9.

Paiva HN, Vital BR. A escolha da espécie florestal. Viçosa: UFV; 2003.

Péllico-Netto S, Brena DA. Inventário florestal. Curitiba: Edição dos Autores; 1997.

Péllico-Netto S, Tello JCR, Wandressem RR. Size and shape of sample units in native forests and plantations. Open Journal of Forestry 2014; 4(4): 379-389. http://dx.doi. org/10.4236/ojf.2014.44043.

Porfírio-da-Silva W, Medrado M J S, Nicodemo MLF, Dereti RM. Arborização de pastagens com espécies florestais madeireiras: implantação e manejo. Colombo: Embrapa Florestas; 2010.

Salles TT, Leite HG, Oliveira SN No, Soares CPB, Paiva $\mathrm{HN}$, Santos FL. Modelo de Clutter na modelagem do crescimento e produção do eucalipto em sistemas de integração lavoura-pecuária-floresta. Pesquisa Agropecuária Brasileira 2012; 47(2): 253-260. http://dx.doi.org/10.1590/ S0100-204X2012000200014.

Santos LDT, Salles NLP, Duarte E.R, Oliveira FLR, Mendes LR. Integração lavoura-pecuária floresta: alternativa para a produção sustentável nos trópicos. Montes Claros: Instituto de Ciências Agrárias, Universidade federal de Minas Gerais; 2010.

Shiver BD, Borders BE. Sampling techniques for forest resource inventory. New York: John Wiley \& Sons; 1996.

Schneider PR, Schneider PSP, Souza CAM. Análise de regressão aplicada a Engenharia Florestal. Santa Maria: FACOS; 2009.

Soares CPB, Paula F No, Souza AL. Dendrometria e inventário florestal. Viçosa: UFV; 2006.

Spurr SH. Forest inventory. New York: Ronal Press; 1952.

Teklehaimanot Z, Jones M, Sinclair FL. Tree and livestock productivity in relation to tree planting configuration in a silvopastoral system in North Wales, UK. Agroforestry Systems 2002; 56(1): 47-55. http://dx.doi. org/10.1023/A:1021131026092.

Vries PG. Sampling theory for Forest inventory: a teach yourself course. Wageningen: Spinger-Verlag; 1986. http:// dx.doi.org/10.1007/978-3-642-71581-5. 